\title{
Posttraumatic growth in mothers after infant admission to neonatal intensive care unit
}

\author{
Handan Boztepe', Figen Inci², Fuat Tanhan ${ }^{3}$
}

This descriptive and cross-sectional study investigated social support and posttraumatic growth in 210 mothers whose newborns were hospitalized at neonatal intensive care unit. The study population consisted of all mothers living in the Niğde provincial center whose babies were admitted to the Level 1 Neonatal Intensive Care Unit between December 2007 and November 2008. The Posttraumatic Growth Inventory, the Impact of Event Scale and the Multidimensional Scale of Perceived Social Support were administered in the mothers' homes. Posttraumatic growth was reported in $75.70 \%(n=210)$ mothers. The impact of event and perceived social support were highly (97.40\%) predictive of posttraumatic growth. Traumatic events are frequently experienced within the healthcare system. Current research findings are therefore extremely valuable for preventing the negative impact of traumatic events on individuals and for transforming the experience into an opportunity for growth.

Keywords: social support; parents; nursing; intensive care units, neonatal

\section{INTRODUCTION}

Hospitalization in neonatal intensive care units (NICUs) is stressful and traumatic for mothers (1), even in the absence of clinical or pathological concerns (2). Several studies involving mothers of infants hospitalized in NICU identified different sources of parental stress, defined as the physical and psychological aspects of a situation that impose demands on individuals $(1,3,4)$. High stress is an important risk factor for poor parent-infant relationships during early childhood and has long-term negative outcomes (5). Research indicates that parents whose infants have been admitted to NICU experience emotional reactions such as guilt, depression, fear, anxiety, acute stress disorder, etc. (6-9).

There is ample evidence indicating that individuals who suffer traumatic events experience many negative physical and psychological consequences, but not all posttraumatic responses are negative $(6,7,10)$. Positive outcomes occurring in individuals after stressful or traumatic events are defined as "perceived benefits", "stress-related growth" or "posttraumatic growth" $(11,12)$. Previous research on posttraumatic growth was mainly focused on life-threatening illnesses such as cancer and coronary heart disease (13-16). Having a newborn admitted to NICU can be a source of serious trauma and crisis for the mother, but also may be related to posttraumatic growth.
The aim of this study was to examine the factors that might predict posttraumatic growth levels in mothers who had an infant admitted to NICU. We hypothesized that social support and impacts of events would predict posttraumatic growth in mothers following NICU experience.

\section{SUBJECTS AND METHODS}

\section{Study population and procedures}

Study population consisted of all mothers living in the Niğde provincial center and whose babies were admitted to the Level 1 NICU between December 2007 and November 2008. Qualified mothers were identified from hospital records and contacted by phone $(\mathrm{N}=493)$. Sampling was

\footnotetext{
${ }^{1}$ Hacettepe University Faculty of Nursing, Pediatric Nursing Department Ankara, Turkey

${ }^{2}$ Niğde University Niğde Zubeyde Hanim Health School Nursing Department, Ankara Niğde, Turkey

${ }^{3}$ Yuzuncu YII University Faculty of Education Sciences Department, Ankara Van, Turkey

The study was presented as oral presentation at the II International VI National Psychiatric Nursing Congress

\section{Correspondence to:}

Handan Boztepe, PhD, RN Assistant Professor; Hacettepe University Faculty of Nursing; Ankara, Turkey; e-mail: boztepehandan@gmail.com

Primljeno/Received: 6. 2. 2014., Prihvaćeno/Accepted: 20. 10. 2014
} 
determined according to the sample size formula ( $n=210)$. Eligible mothers whose babies were hospitalized in NICU for at least one day in the previous year were included. These mothers were literate and agreed to participate after being informed about the study.

The procedure parents' information was provided by the hospital manager and these mothers were contacted by phone and informed about the study. Mothers who agreed to participate in the study were visited at their home, where they completed the self-administered questionnaires. All mothers were literate and provided written informed consent to participate in the study. The study protocol was approved by the Niğde University Ethics Committee. Institutional permission was granted from the hospital. All participants completed the questionnaires by themselves. Birth age and time of discharge from the NICU were ignored in this study.

\section{Survey instruments}

Demographic data and information related to the intensive care experience were collected via questionnaire. Additionally, the following scales were administered:

\section{Posttraumatic Growth Inventory (PTGI)}

This inventory developed by Tedeschi and Calhoun assesses positive changes in an individual following a traumatic incident (11). Ratings are made on a 6-point Likert scale from 0 to 5 . The potential total scores range from 0 to 105 , with a higher score indicating greater growth. In this study, internal reliability for PTGI was 0.95 and reliability for the subscales ranged from 0.64 to 0.86 .

\section{Impact of Event Scale-Revised (IES-R)}

Originally developed by Weiss and Marmar (1997), this instrument was adapted into Turkish by Çorapçığlu and colleagues, with a Cronbach's alpha coefficient of $0.93(17,18)$. The scale consists of 22 items. In this study, internal reliability for IES-R was 0.95 and reliability for the subscales ranged from 0.82 to 0.93 . The Cronbach's alpha coefficient of the scale was calculated as 0.95 in the current study.

\section{Multidimensional Scale of Perceived Social Support (MSPSS)}

The MSPSS was originally developed by Zimet et al. (1988) to investigate the level of social support received from different sources (19). The reliability and validity of the instrument in Turkish was published by Eker and Arkar (1995), with a Cronbach's alpha coefficient of 0.88 (20). Each item is rated from 1 to 7 on a 7-point Likert scale, with higher scores indicating greater support. In this study, internal reliability for MSPSS was 0.77 and reliability for the subscales ranged from 0.45 to 0.97 .

\section{Statistical analyses}

Using a two-step cluster analysis, we categorized the total score obtained from the PTGl into a variable coded as "little postraumatic growth"/"more posttraumatic growth". This type of analysis was done to create homogeneous subsamples (clusters) of our heterogeneous sample in order to avoid any possible sampling bias. Hierarchical Binary Logistic Regression was used for modelling the association between the outcome variable (growth after trauma) and the predictor variables (impact of trauma and social support) (21). All data analyses were completed using the SPSS version 16.0 (Chicago, SPSS Inc.).

\section{RESULTS}

More than half of the babies (67.1\%) were admitted after birth and 69\% underwent treatment for jaundice. Most (84.8\%) infants stayed less than eight days in NICU and $88.6 \%$ of the mothers had no prior NICU experience (Table 1). The mean PTGl score was $75.70 \pm 22.17$. The results of cluster analysis yielded a mean growth level score of 37.64 $(\mathrm{SD}=17.63)$ for 39 subjects coded as Cluster 1. This sub-sample was defined as individuals who experienced little growth after trauma. Conversely, the category coded as Cluster 2 comprised 171 subjects who were defined as individuals that showed considerable growth after trauma and had a mean score of 84.38 (SD=11.27). Finding an acceptable goodness-of-fit, we tested statistical significance of the coefficients of predictor variables on the outcome. The intercept was statistically significant $(\beta=1.472 ; p<0.0001)$. Table 2 summarizes $p$ values for each variable in the model.

The effects of predictor variables included in the model on the outcome variable are listed in subcategories in Table 3. All predictor variables were significantly associated with posttraumatic growth $(p<0.05)$, hence they remained in the model. These predictor variables explained $97.4 \%$ of variance in the outcome; thus, we suggest that the variables included in the model explained the outcome very well. Table 4 shows that every increment in the predictors resulted in a level of increment in the odds of observing the outcome variable. The odds ratios were not statistically significant since the category coded as 1 indicated 'little posttraumatic growth'. Based on this, not all variables in the regression model were significantly predictive of little posttraumatic growth. In other words, the subdimensions of the MSPSS predicted relief, escape, over-stimulation and post- 
TABLE 1. Description of maternal, obstetric and infant characteristics $(\mathrm{N}=210)$

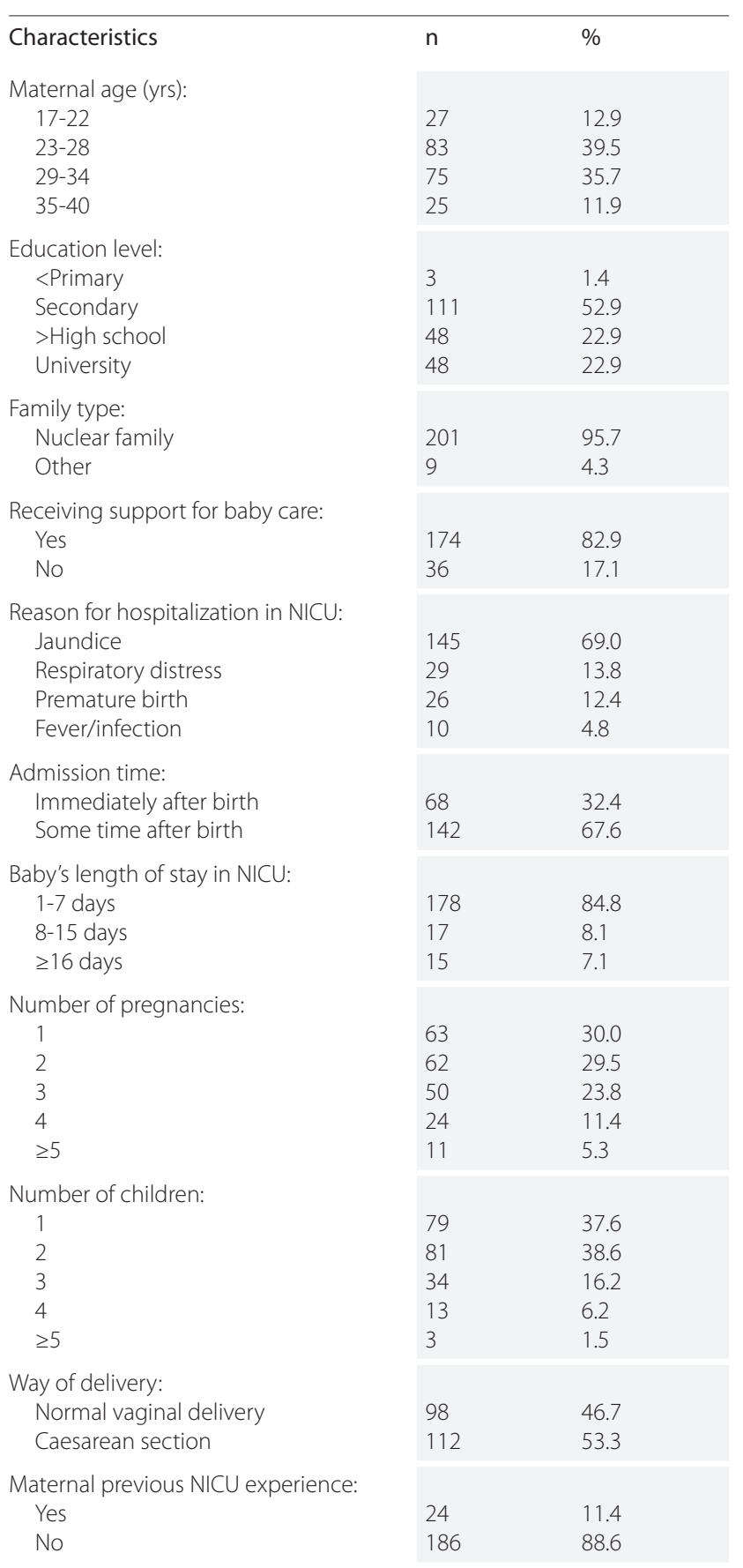

NICU = neonatal intensive care unit

TABLE 2. Post-Traumatic Growth Inventory (PTGI) two-step cluster analysis results

\begin{tabular}{|c|c|c|c|c|}
\hline \multirow{2}{*}{ Cluster } & \multicolumn{4}{|c|}{ PTGI total score } \\
\hline & $\mathrm{n}$ & $\%$ & Mean & SD \\
\hline PTG lower (coded as 1) & 39 & 18.6 & 37.64 & 17.63 \\
\hline PTG high (coded as 2) & 171 & 81.4 & 84.38 & 11.27 \\
\hline Total & 210 & 100 & 75.70 & 22.17 \\
\hline
\end{tabular}

TABLE 3. Variables not included in the initial model

\begin{tabular}{llll}
\hline Predictor & Score & SD & p \\
Social support family & 5.088 & 1 & 0.024 \\
Social support friends & 6.190 & 1 & 0.013 \\
Social support significant other & 5.323 & 1 & 0.021 \\
Impact of event relief & 7.121 & 1 & 0.008 \\
Impact of event escape & 10.951 & 1 & 0.001 \\
Impact of event over-stimulation & 6.649 & 1 & 0.010 \\
Error chi-square $\left(x^{2} \beta 0\right)$ & 152.312 & 11 & $<0.0001$
\end{tabular}

TABLE 4. Coefficient estimates of model variables

\begin{tabular}{lllllll}
\hline Predictor & $\beta$ & SE & Wald & SD & $p$ & $\operatorname{Exp}(\beta)$ \\
Social support family & -0.021 & 0.263 & 0.006 & 1 & 0.936 & 0.979 \\
Social support friends & 0.058 & 0.093 & 0.393 & 1 & 0.531 & 1.060 \\
$\begin{array}{l}\text { Social support } \\
\text { significant other }\end{array}$ & 0.039 & 0.343 & 0.013 & 1 & 0.910 & 1.039 \\
$\begin{array}{l}\text { Impact of event relief } \\
\text { Impact of event escape }\end{array}$ & -0.167 & 0.258 & 0.417 & 1 & 0.518 & 0.847 \\
$\begin{array}{l}\text { Impact of event over- } \\
\text { stimulation }\end{array}$ & 0.199 & 0.443 & 0.202 & 1 & 0.653 & 1.220 \\
Intercept & & & & & & \\
& -21.190 & 6.723 & 9.936 & 1 & 0.002 & 0.000
\end{tabular}

traumatic growth, and the findings were statistically significant.

\section{DISCUSSION}

We found the levels of social support and the impact of event to have a statistically significant association with posttraumatic growth in the mothers having previous NICU experience. The prevalence of PTG for mothers was $75.7 \%$, i.e. higher than the findings in similar studies in cancer survivors, patients and students $(15,22-26)$. This higher prevalence might be related to the severity of trauma. Mothers might demonstrate higher PTG than survivors with more serious illness because infants admitted to Level 1 NICU did not experience serious or fatal illness. Thus, higher PTG may be associated with the babies' recovery at the end of their admission to NICU. The mothers' cultural background and religious faith may be related to higher PTG. Additionally, according to Tedeschi and Calhoun, women are more prone to posttraumatic growth (11).

The results of the modelling and regression analysis in the current study showed that social support and the impact of event explained $79.4 \%$ of variance in posttraumatic growth. Social support and the impact of event were major predictors of posttraumatic growth outcomes. Our findings are consistent with the results of studies investigating the association between social support and posttraumatic growth 
$(13,27,28)$. Leung et al. (2010) identified significant association between greater social support and posttraumatic growth (28). In a study investigating posttraumatic growth following childbirth, Sawyer et al. (2012) found no association between PTG and social support (29). Similarly, no statistically significant association was found in another study investigating coping strategies, social support, attachment styles and posttraumatic growth in cancer survivors (14). The results of our current study showed social support to predict posttraumatic growth and this finding is consistent with Tedeschi and Calhoun's theoretical model $(11,12)$.

The impact and magnitude of traumatic event is an important variable in predicting PTG. Some previous studies have reported positive association between the impact of event and posttraumatic growth $(16,26,30,31)$. Conversely, a recent study by Arikan and Karanci (2012) found negative correlation between traumatic events and posttraumatic growth (32). In the current study, the mean IES score was 17.49 ( $S D=18.64)$, indicating a low negative impact of event. It is possible that lesser perception of the event facilitates posttraumatic growth.

The findings of the current study are extremely valuable for preventing negative impacts of traumatic events on individuals and for transforming the experience into an opportunity for growth. As health professionals who work most closely with patients and families following trauma, nurses are in a position to ensure patients' awareness of the social support available. Through nursing interventions, the negative impacts of NICU admissions can be minimized. Nurses can contribute greatly to transforming the negative effects of trauma into a positive opportunity for growth.

\section{NOVČANA POTPORA/FUNDING \\ Nema/None}

\section{ETIČKO ODOBRENJE/ETHICAL APPROVAL}

Nije potrebno/None

\section{DOPRINOSI AUTORAVDECLARATION OF AUTHORSHIP}

Svi autori jednako su doprinijeli izradi rada/All authors have equally contributed to a manuscript writing

\section{SUKOB INTERESA/CONFLICT OF INTEREST}

Autori su popunili the Unified Competing Interest form na www.icmje.org/ coi_disclosure.pdf (dostupno na zahtjev) obrazac i izjavljuju: nemaju potporu niti jedne organizacije za objavljeni rad; nemaju financijsku potporu niti jedne organizacije koja bi mogla imati interes za objavu ovog rada u posljednje 3 godine; nemaju drugih veza ili aktivnosti koje bi mogle utjecati na objavljeni rad./All authors have completed the Unified Competing Interest form at www.icmje.org/coi_disclosure.pdf (available on request from the corresponding author) and declare: no support from any organization for the submitted work; no financial relationships with any organizations that might have an interest in the submitted work in the previous 3 years; no other relationships or activities that could appear to have influenced the submitted work.

\section{REFERENCES}

1. Shields-Poe D, Pinelli J. Variables associated with parental stress in Neonatal Intensive Care Units. Neonatal Network.1997;16:29-37.

2. Kaaresen PI, Rønning JA, Ulvund SE, DahI LBA. Randomized, controlled trial of the effectiveness of an early-intervention program in reducing parenting stress after preterm birth. Pediatrics. 2006;118:9-19. http://dx.doi.org/10.1542/peds.2005-1491

3. Spear ML, Leef K, Epps S, Locke R. Family reactions during infant's hospitalization in the neonatal intensive care unit. Am J Perinatol. 2002;19:205-13. http://dx.doi.org/10.1055/s-2002-28484

4. Matricardi R, Agostino C, Fedeli R, Montirosso R. Mothers are not fathers: differences between parents in the reduction of stress levels after a parental intervention in a NICU S. Acta Pædiatr. 2013;102:8-14. http://dx.doi.org/10.1111/apa.12058

5. Muller-Nix C, Forcada-Guex M, Pierrehumbert B, Jaunin L, Borghini A, Ansermet, F. Prematurity, maternal stress and mother-child interactions. Early Hum Develop.2004;79:145-58. http://dx.doi.org/10.1016/j.earlhumdev.2004.05.002

6. Erdem Y. Anxiety levels of mothers whose infants have been cared for in unit level -I of a neonatal intensive care unit in Turkey. J Clin Nurs.2010;19:1738-47. http://dx.doi.org/10.1111/j.1365-2702.2009.03115.x

7. Güngör I, Oskay U, Kizilkaya NB. Bio psychosocial risk factors for preterm birth and postpartum emotional well-being: a case-control study on Turkish women without chronic illnesses. J Clin Nurs.2011;20:653-65. http://dx.doi.org/10.1111/j.1365-2702.2010.03532.x

8. Singer LT, Fulton $\mathrm{S}$, Kirchner $\mathrm{HL}$, et al. Longitudinal predictors of maternal stress and coping after very low-birth-weight birth. Arch Pediat Adol Med. 2010;164:518-24. http://dx.doi.org/10.1001/archpediatrics.2010.81

9. Nicholaou M, Glazebrook C. Emotional support for families of sick neonates. Pediatr Child Health. 2008;18:196-9. http://dx.doi.org/10.1016/j.paed.2007.12.015

10. Rosario M, Provenzi L, Guido C, Renato B, NEO-ACQUA Study Group. Measuring maternal stress and perceived support in 25 Italian NICUs. Acta Pædiatr. 2012;101:136-42. http://dx.doi.org/10.1111/j.1651-2227.2011.02440.x

11. Tedeschi RG, Calhoun LG. The posttraumatic growth inventory: measuring the positive legacy of trauma. J Trauma Stress. 1996;9:455-71. http://dx.doi.org/10.1002/jts.2490090305

12. Tedeschi RG, Calhoun LG. Posttraumatic growth: conceptual foundations and empirical evidence. Psychol Inq. 2004;15:1-18. http://dx.doi.org/10.1207/s15327965pli1501_01

13. Nenova M, DuHamel K, Zemon V, Rini C, Redd WH. Posttraumatic growth, social support, and social constraint in hematopoietic stem cell transplant survivors. Psychooncology. 2013;22:195-202. http://dx.doi.org/10.1002/pon.2073

14. Schmidt S, Blank T, Bellizzi K, Park C. The relationship of coping strategies, social support, and attachment style with posttraumatic growth in cancer survivors. J Health Psychol. 2012;17:1033-40. http://dx.doi.org/10.1177/1359105311429203

15. Silva SM, Moreira HC, Canavarro MC. Examining the links between perceived impact of breast cancer and psychosocial adjustment: the buffering role of posttraumatic growth. Psycho-Oncology. 2012;21:409-18. http://dx.doi.org/10.1002/pon.1913

16. Yonemoto T, Kamibeppu K, Ishii T, Iwata S, Tatezaki S. Posttraumatic stress symptom (PTSS) and posttraumatic growth (PTG) in parents of childhood, adolescent and young adult patients with high-grade osteosarcoma. Int J Clin Oncology. 2012;17:272-5. http://dx.doi.org/10.1007/s10147-011-0286-3

17. Weiss DS, Marmar CR. The impact of event scale-revised. In: Wilson JP, Keane TM, editors. Assessing psychological trauma and PTSD. 1st ed. New York: Guilford Press; 1997. 
18. Corapçıoğlu A, Yargıç I, Geyran P, Kocabaşoğlu N. The reliability and validity of the Impact of Event Scale (IES-R) Turkish Version [TR]. New Symposium J. 2006;44:14-22.

19. Zimet GD, Powell SS, Farley GK, Werkman S, Berkoff KA. Psyhometric characteristic of the Multidimensional Scale of Perceived Social Support. J Pers Assess.1990;55:610-7. http://dx.doi.org/10.1207/s15327752jpa5503\&4 17

20. Eker D, Arkar H. Factor structure, validity and reliability of the Multi-Dimensional Scale of Social Support [TR]. Turkish J Psychol. 1995;10:45-55.

21. Kayri M. Two-step cluster analysis in researches: A case study. Eur J Education Res. 2007;28:177-89.

22. Li Y, Cao F, Cao D, Wang Q, Cui N. Predictors of posttraumatic growth among parents of children undergoing inpatient corrective surgery for congenital disease. J Pediatr Surg. 2012;47:2011-21. http://dx.doi.org/10.1016/j.jpedsurg.2012.07.005

23. Bronwyn A, Shakespeare-Finch MJ, Scott JL. Posttraumatic growth after cancer: the importance of health-related benefits and newfound compassion for others. Support Care Cancer. 2012;20:749-75. http://dx.doi.org/10.1007/s00520-011-1143-7

24. Yonemoto T, Kamibeppu K, Ishii T, Iwata S, Hagiwara Y, Tatezaki S. Psychosocial outcomes in long-term survivors of high-grade osteosarcoma: a Japanese single-center experience. Anticancer Res. 2009;29:4287-90.

25. Tanrıverdi D, Esen S, Can G. Posttraumatic growth and social support in Turkish patients with cancer. Asian Pac J Cancer Prev. 2013;9:4311-4.
26. Taku K, Calhoun LG, Tedeschi RG, Gil-Rivas V, Kilmer RP, Cann A. Examining posttraumatic growth among Japanese university students. Anxiety Stress Coping. 2007;20:353-67. http://dx.doi.org/10.1080/10615800701295007

27. Elçi $O$. The predictive value of social support, stress levels and coping strategies on posttraumatic growth and burnout in families of autistic children [TR]. Middle Eastern Technical University, Department of Psychology, Master`s Thesis, 2004.

28. Leung YW, Gravely-Witte S, Macpherson A, Irvine J, Stewart DE, Grace SL. Post-traumatic growth among cardiac outpatients: degree comparison with other chronic illness samples and correlates. J Health Psychol. 2010;15:1049-63 http://dx.doi.org/10.1177/1359105309360577

29. Sawyer A, Ayers S, Young D, Bradley R, Smith H. Posttraumatic growth after childbirth: A prospective study. Psychol Health. 2012;27:362-77. http://dx.doi.org/10.1080/08870446.2011.578745

30. Colville G, Cream P. Post-traumatic growth in parents after a child's admission to intensive care: maybe Nietzsche was right? Intensive Care Med. 2009:35:919-23. http://dx.doi.org/10.1007/s00134-009-1444-1

31. Mystakidou K, Parpa E, Tsilika E, Pathiaki M, Galanos A, Vlahos L. Traumatic distress and positive changes in advanced cancer patients. Am J Hosp Palliat Care. 2007;24:270-6. http://dx.doi.org/10.1177/1049909107299917

32. Arıkan G, Karancı N. Attachment and coping as facilitators of posttraumatic growth in Turkish university students experiencing traumatic events. J Trauma Dissociation. 2012;13:209-25. http://dx.doi.org/10.1080/15299732.2012.642746

\title{
Posttraumatski rast kod majki novorođenčadi primljene u neonatalnu jedinicu intenzivnog liječenja
}

\author{
H. Boztepe, F. Inci, F. Tanhan
}

Ova deskriptivna poprečna studija ispitivala je društvenu potporu i posttraumatski rast u 210 majki čija je novorođenčad hospitalizirana u neonatalnoj jedinici intenzivnog liječenja. Ispitivana populacija obuhvatila je sve majke koje žive u pokrajini Niğde, a čija je novorođenčad primljena na 1. razinu neonatalne jedinice intenzivnog liječenja u razdoblju od prosinca 2007. do studenoga 2008. godine. Majkama su kući dostavljeni upitnici Posttraumatic Growth Inventory, Impact of Event Scale i Multidimensional Scale of Perceived Social Support. Posttraumatski rast je opisalo 75,70\% od 210 majki. Utjecaj događaja i doživljena društvena potpora u visokoj su mjeri (97,40\%) pretkazivali posttraumatski rast. Kako se traumatski događaji često doživljavaju unutar zdravstvenog sustava, nalazi dobiveni ovim istraživanjem veoma su vrijedni za sprječavanje negativnog utjecaja traumatskih događaja na pojedinca te za pretvaranje takvog iskustva u priliku za rast.

Ključne riječi: društvena potpora; roditelji; njega bolesnika; jedinica intenzivnog liječenja, neonatalna 